\title{
The Importance of Instructional Materials in Nurse Education in the North West and South West Regions of Cameroon: The Nurse Teacher's Perspective
}

\author{
Metuge Edna Mesue (MNE) \\ Higher Institute of Applied Medical Sciences, P. O. Box 412, Buea, South West Region of Cameroon \\ *Corresponding Author: Metuge Edna Mesue (MNE), Higher Institute of Applied Medical Sciences, $P$. \\ O. Box 412, Buea, South West Region of Cameroon
}

\begin{abstract}
Learning and teaching are the concerns of trained teachers. The more senses are stimulated in the teaching process, the more learning will occur. Learning can be reinforced, made interesting and memorable for learners with the use of instructional materials. This study investigated, "The Use of Instructional Materials in Nurse Education: Actual use, Barriers and Attitudes: The Nurse Teachers' Perspective." The general objective of the study was to assess the use of five instructional materials in nurse education. The descriptive survey research design was used for this study. Out of a target population of 105 nurse teachers in North West and South West Regions, 91 were purposefully selected as the sample. A questionnaire was administered and 76 respondents responded giving a response rate of $84 \%$. Data were analysed using the Statistical Package for Social Science, version 17 (2010, Atlanta Georgia). The results showed that the teachers who have been teaching longer (57.9\%) actually used instructional materials. More teachers, (53.9\%) were found in government nursing schools than in private schools (46.1\%). The results also showed that the chalkboard, manikins, handouts, flipcharts and power point are actually being used, scoring 74\%, $57 \%, 51 \%, 51 \%$ and $55 \%$ respectively, with barriers such as: expensive to own, expertise skills required, lack of time and difficult to produce, that impede their use and affect attitudes towards their use. The results mean that the five selected instructional materials are actually being used by nurse teachers and need encouragement from government and private proprietors in their purchase, in order to make them always available for use.
\end{abstract}

Keywords: Instructional Materials, Nurse, Nurse Education, Teachers, Cameroon.

\section{INTRODUCTION}

Just as the instructional methods are the approaches or processes used for instructor-learners communications, instructional materials are the resources and tools used as vehicles to help communicate the information. Often the terms instructional strategy and teaching technique serve to describe both the methods and the materials used in teaching (Weston and Cranston, 1986). Instructional materials are tangible substances and real objects that provide the audio and/or visual component necessary for learning. Many of them can be manipulated. They stimulate a learner's senses and may have the power to arouse emotions. Instructional materials help the teacher make sense of abstractions and simplify complex messages (Babcode and Miller 1994). The term instructional materials, also referred to as tools and aids includes both print and non print media that are intended to supplement, not replace, actual teaching. Research indicates that the use of audio visual aids facilitate learning (Haggard, 1989; Rankin and Stallings, 1990). However, the use of instructional materials in developed countries is more significant than in underdeveloped countries due to limited resources and technology. The purpose of instructional materials is to help the nurse teacher deliver a message creatively and clearly. The advantage of a multi media approach in teaching is to assist learners in gaining increased awareness and skills and in retaining more effectively what they learn (Rankin and Stallings, 1990). Instructional materials add variety to the teaching- learning experience (Babcode and Miller, 1994), reinforce learning and potentially bring realism to the experience as well as saving time and energy on the part of both the teacher and the learner (Adeyanju 2003).

Audiovisual education emerged as a discipline in the 1920s. This happened when a visual instruction 
movement arose, which encouraged the use of visual materials to make abstract ideas more concrete to pupils. As sound technology improved, the movement became known as audiovisual instruction. Educators at that time viewed audiovisuals only as aids to teachers. Not until world war II, when the armed services used audiovisual materials to train large numbers of persons in short periods of time, did the potential of these devices as primary sources of instruction become apparent. In the1950s and 1960s, development in communications theory and systems concepts led to studies of the educational process, its elements and their interrelationships; among these elements are the teacher, the teaching methods, the information conveyed, the materials used, the student, and the student's responses. As a result of these studies, the field of audiovisuals shifted its emphasis from devices and materials to examination of the teaching-learning process. Hence, if instructional materials are well organized, well constructed and properly presented, a successful teaching-learning process would be achieved.

\section{Problem Statement}

Teaching and learning is the science of instruction focused and restricted to the domain of materials and educational aids (Doring, 2009). It represents a kind of specialized science of instructions and has the function to consider teaching and in particular instruction as a whole under aspect of such aids. That is, it has to analyze the pre-requisite conditions and results of teaching with special emphasis on the choice of media. Nacino\& Desmond (1992) define science of instructional material as the use of curriculum materials, educational materials, audiovisual materials in identifying and discussing teaching and learning. Instructional materials are generally those materials which the teacher employs to facilitate the teaching/learning process. Such materials span across the five senses of the human body (sight, hearing, smell, touch and taste). Tambo (2003) holds that the lack of instructional materials will often make teachers to rush through explanation of complicated concepts, expecting students to learn them within the few minutes of the lesson time.

In nursing schools in Cameroon, clinical nurses and medical doctors are those responsible for teaching / training of student nurses. While expert clinicians are often ill equipped for the task of teaching, Nugent et al., (1999) have pointed out that they will exhibit strong personal self-efficacy in the clinical setting but nurse teacher self-efficacy may be lacking, not for lack of desire, but for lack of formal preparation as a teacher. Prieto\&Altmaier (1994) argue that a heightened sense of efficacy in teachers affects their perceived and actual ability to teach more effectively and is a strong mediating variable in subsequent student achievement. A growing body of research suggests that teacher efficacy may underlie critical instructional decisions such as the use of time, choice of classroom management strategy, and questioning techniques. Thus, due to inadequate preparation for the teaching role, these new nurse teachers are set up for trying times, if not failure. Entering an environment of new rules and expectations, the clinician who once felt like an expert now becomes the novice.

Training competent nurses requires substantial investment on the part of both the government and private schools of nursing. Indeed, research by Princeton and Gaspar (1992) revealed that administrators and other faculty staff spend an inordinate amount of time working with inexperienced nurse teachers who have no formal education in curriculum development, teaching methods/instructional materials, evaluation and progression of nursing students. This also reflects what is happening in nursing schools in Cameroon. Nugent et al., (1999) suggest that if new teachers are to be successful without formal education tracks, mentoring by experienced nurse teachers is the key. Mentoring could serve as the positive coaching, supporting, and guiding force to developing increased nurse teacher self efficacy that the new nurse teacher needs. However, with the graying of the present faculty and the decline in the numbers of nurses preparing to teach nursing, experienced mentors may be scarce. To quote Fitzpatrick and Heller (1980) "incredibly, we are now confronted with the task of teaching the teachers to teach." In general therefore, it could be argued that to improve on teaching and learning in nursing education in order to meet national and international standards, it is necessary to know the actual use of instructional materials in nursing schools. It is against the above background that the study sought to investigate the use of five commonly available instructional materials in education by nurse teachers in the South West and North West Regions of 
The Importance of Instructional Materials in Nurse Education in the North West and South West Regions of Cameroon: The Nurse Teacher's Perspective

\section{Cameroon.}

\section{RESEARCH OBJECTIVES}

The main objective was to investigate the use of five selected instructional materials in nurse education. Specifically, to assess the actual use of chalkboard, handouts, flip charts, manikins and power point in nurse education; to identify barriers to the use of chalkboard, handouts, flip charts, manikins and power point in nurse education.

\subsection{Theoretical Framework}

\subsubsection{Behaviourist Theory}

Behaviourism is primarily concerned with observable and measurable aspects of human behaviour. In defining behaviour, behaviourist learning theories emphasize change in behaviour that result from stimulus-response associations made by the learner. Behaviour is directed by stimuli. An individual selects one response instead of another because of prior conditioning and psychological drives existing at the moment of the action (Parkay\& Hass, 2000).Behaviourists assert that the only behaviours worthy of study are those that can be directly observed, thus, it is actions, rather than thoughts or emotions which are the legitimate object of study. Behaviourist theory does not explain abnormal behaviour in terms of the brain or its inner workings. Rather, it posits that all behaviour is learned habits, and attempts to account for how these habits are formed. In assuming that human behaviour is learned, behaviourist also hold that all behaviours can also be unlearned, and replaced by new behaviours: that is when behaviour becomes unacceptable, it can be replaced by an acceptable one. A key element to this theory of learning is the rewarded response. The desired response must be rewarded in order for learning to take place (Parkay\& Hass, 2000).

John B. Watson (1878-1958) and B.F. Skinner (1904-1990) are the two principal originators of behaviourist approaches to learning. Watson (1924) believes that human behaviour results from specific stimuli that elicit certain responses. Watson's basic premise is that conclusions about human development should be based on observation of overt behaviour rather than speculation about subconscious motives or latent cognitive processes (Shaffer, 2000). Expanding on Watson's basic stimulus-response model, Skinner developed a more comprehensive view of conditioning, known as operant conditioning. His model is based on the premise that satisfying responses are conditioned, while unsatisfying ones are not. Operant conditioning is the rewarding of part of a desired behaviour or a random act that approaches it. Skinner remarks that "the things we call pleasant have an energizing or strengthening effect on our behaviour" (Skinner, 1972, p. 74).

For the purpose of this study, behaviourist teaching methods, for which instructional materials constitute an important part, tend to rely on so-called "Skill and Drill" activities to provide the consistent repetition necessary for actual reinforcement of response patterns. Other methods include question (Stimulus) and answer (response) framework in which questions are of gradually increasing difficulty, guided practice, and regular review of materials, this helps the nursing students to build their psychomotor skills through practice that can be evident by a change in behaviour upon graduation. Behaviourist methods also typically rely heavily on the use of positive reinforcements such as verbal praise, good grades, and prizes. Behaviourist teaching methods have proved most successful in areas where there is a "correct" response or easily memorized material.

\subsubsection{Cognitive Theory}

Dissatisfaction with behaviourism's strict focus on observable behaviour led educational psychologists such as Jean Piaget and William Perry to seek an approach to learning theory that paid more attention to what goes on "inside the learners head". They developed a cognitive approach that focused on mental processes rather than observable behaviour. Common to most cognitive approaches is the idea that comprises symbolic mental representations, such as propositions and images, together with a mechanism that operates on those representations. Knowledge is seen as something that is actively constructed by learners based on their existing cognitive structures. Therefore, it is relative to their stage of cognitive development; understanding the learner's existing intellectual framework is central to understanding the learning process. The major goal of teaching is to facilitate active thinking and mental processing. Because knowledge is actively constructed, 
learning is presented as a process of active discovery. The role of the instructor is not to drill knowledge into students through consistent repetition, or to goad them into learning through carefully employed rewards and punishments. Rather, the role of the nurse teacher is to facilitate discovery by providing the necessary resources and by guiding learners as they attempt to assimilate new knowledge to old and to modify the old to accommodate the new. Nurse teachers must thus take into account the knowledge that the leaner currently possesses when deciding how to construct the curriculum and to present sequence, and structure new material.

Unlike behaviourist learning theory, where learners are thought to be motivated by extrinsic factors such as rewards and punishment, cognitive learning theory sees motivation as largely intrinsic. Because it involved significant restructuring of existing cognitive structures, successful learning requires a major personal investment on the part of the learner (Perry, 1999). Learners must face up to the limitations of their existing knowledge and accept the need to modify or abandon existing beliefs. Without some kind of internal drive on the part of the learners to do so, external rewards and punishments such as grades are unlikely to be sufficient. Cognitivist teaching methods aim to assist students in assimilating new information to existing knowledge, and enabling them to make the appropriate modifications to their existing intellectual framework to accommodate that information. Piaget in his theory of cognitive development emphasizes that children must interact with the environment to develop cognitively. Piaget's theory urges teachers to assume that children have build-in desire to learn because they possess an innate urge to make sense on what they observe and experience (Biehler\& Snowman, 1986).

For the purpose of this study, thus, while cognitivists allow for the use of skill and drill exercises in the memorization of facts, formulae and lists, they place greater importance on strategies that help students to actively assimilate and accommodate new materials. For instance, asking students to explain new materials in their own words can assist them in assimilating it by urging them to reexpress the new ideas in their existing vocabulary. In like manner, providing students with set of questions to structure their reading makes it easier for them to relate it to previous materials by highlighting certain parts and to accommodate the new material by providing a clear organizational structure. Hence a variety of teaching methods supported by teaching materials should be used by nurse teachers during instruction, to allow students interact and construct meaning to the events that they experience.

\subsection{Connectivism (a learning theory for the digital age)}

Connectivism is a learning theory enacted by George Siemens in 2005. Siemens advanced this theory because of the limitations of the theories of behaviourism, cognitivism\& constructivism to explain learning in this information age. The following principles are embedded in the theory of connectivism: learning and knowledge rest in diversity of opinions; learning may reside in nonhuman appliances; nurturing and maintaining connections are needed to facilitate continual learning; ability to use connections between fields, ideas and concepts is a core skill; currency (accurate, up to date knowledge) is intent of all connectivist-learning activities and decision making is itself a learning process. Choosing what to learn and the meaning of incoming information is seen through the lens shifting reality. While there is a right answer now it may be wrong tomorrow due to alteration in the information climate affecting the decision Seimens, 2005).

The theory advances that knowledge rest in diversity of opinions. This is consistent with the study because nurse teachers' attitudes rest in diverted opinions. It advocates for accurate up-to-date knowledge. This is in line with the study because nurse teachers' up-to-date knowledge on selected instructional materials would help in curbing any barriers to their use. It further holds that decisions ought to change based on changing realities. This is true with the study because teachers are expected to take decisions based on current realities with evidence on the specific instructional material in use.

\subsection{Conceptual background}

The use of instructional materials in education, although consistently shown to aid in learning, must be carefully designed. Instructional materials that steer the learner to the exciting or entertaining 
aspects of presentation rather than encouraging thoughtful analysis of the underlying meaning may interfere with the intent of the lesson, (Rogers and Frieberg, 1994). In addition, Dwyer, as cited in Williams and Dwyer, (1999) suggests that instructional materials must be properly used in the educational setting since visualization alone does not function to maximize student achievement. In the same vein Adeyanju (2003) recommends that visual aids must be ones that students are used to seeing and should be related to their background. He further argues that many objects have a specific cultural meaning that has no meaning at all in other cultures. People and clothing in a picture may look so different that the student does not relate to them as similar people. He therefore maintains that instructional materials must be adequately prepared, have a clear purpose, be previewed, and introduced, shown to students under good conditions, discussed and applied to the lesson.

Effective use of power points requires that video equipments be set up in advance and operation checked. The teacher should ensure that all trainees can see the screen well, limit the number of lines of text per slide and limit to one learning objective per slide (ibid). He adds that teachers should select and use pictures that are closely related to their lesson, and avoid selecting pictures just on the basis of their beauty or colourfulness. Pictures should look as natural as possible because students who are not used to looking at pictures may see something entirely different from what was planned.

To effectively use photographic instructional materials, teachers should ensure students are able to recognize contextual clues that are useful in interpreting phenomena depicted in the pictures and have a clear view of them, (Tambo, 2003). To effectively use models, teachers should ensure they are durable enough to withstand manipulation or touching by many students. The size of the model should fit the size of the group. Thus, a model should be large enough to be viewed clearly by all students during demonstrations. If to be examined on individual or small group basis, they should be many enough to go round. Models should be related to real things by using a picture of a real thing in association with the model (ibid).

\subsection{Five selected Instructional Materials}

There are a great variety of materials around that can be used to make our leaning more vivid and more interesting. Butcher (2003) argues that each medium has strength and can complement other media to exploit the strengths and overcome potential weaknesses. The study investigated the following five instructional materials:

\subsubsection{The Ordinary chalkboard}

This is the most commonly used type of display board and one would find it difficult to think of a classroom without a chalkboard of one kind or colour. The chalkboard has many advantages: It is one of the cheapest materials to produce. It is adapted to both small and large group work. During lessons, pupils can use the chalkboard for practice exercises and illustration necessary for class observation, discussion and appreciation. The chalk board is also one of the cheapest instructional materials to use. The main software required is chalk and a duster. With these you can write and erase as many times as you need. It is very useful to teachers when they are developing outlines and summaries together with pupils as the lesson progresses (Tambo, 2003). Wilkins (1976) holds that one of the attractions of the chalkboard for the pupil is that of seeing things happening before his own eyes and in that way his interest is maintained as he watches items appearing. In the same vein, Farrant (1980) maintains that the chalkboard, because it comes in a variety of colours, is still the most common teaching aid and one of the most useful. The chalkboard as Farrant attests stands out as visual testimony of the master's work. In addition, the use of the blackboard as a visual aid for oral expression is ideal for children to first discuss situations, in course of which ideas would flow. These ideas could be written on the chalkboard. For more effective teaching, the students could be shown the picture of the situation under discussion. Tambo (2003) maintains that the chalkboard can be adapted to small and large group work. Sketches and drawing put on the chalkboard can be to the advantage of the whole class. The chalkboard can equally serve as material for practice exercises and illustrations necessary for class observation. The chalkboard is well adapted to a situation in which the teacher develops outlines and makes summaries. Furthermore the cited works portray the chalkboard as being too teacher centred. This means that children sit and listen while the teacher puts his/her work on the chalkboard. The chalkboard can equally stand as visual testimony of the child's work. Here the pupil can be given the chalk to produce his/her own images. Kent (1969) discusses 
the various teaching aids showing their importance to the teaching profession. He sees the chalkboard as a basic aid to illustrating and recapitulating. Points and sketches can be made on the chalkboard when students are listening to a radio broadcast.For effectiveness in use, the teachers must ensure that what is written is not hidden from the students, chalkboard is kept clean after use, writing and drawing are large enough to be readable from any corner of the room, and the accessories are in place to avoid interruption of the lesson (Tambo, 2003; Ashley, 2005). However, the following barriers have been noted: rough surface due to poor design, erasing, inability to write well on the board due to lack of interest or personal weakness of the teacher; non availability, lack of time, lack of accessories and lack of water to wash hands after use (Adeyanju, 2003)

\subsubsection{PowerPoint}

Ensure you do not block students view, check that they can see and hear the instructional material. If need be change the seating arrangements. Power point is an extremely popular presentation package and alternative to using Over Head Projector for the production of interesting and visually attractive presentations. Refrain from using power point just because it exists, for technology should not drive the selection of the teaching aid, it should be chosen according to it fitness for purpose in that particular teaching situation. Power point is flexible both in content of presentation and information display (graphs, drawings, tables, organizational charts). Keep the presentation simple and clear; limit the number of slides and bullet points on slides (not more than 5 points and not more than 12 slides for a 10minutes presentation. It is very useful to have prepared power point presentation before hand. Limit to one objective to a slide (Doyle\&Robson, 2002). Furthermore, the power point is great if used as a tool for elaboration, or as an aid. It helps visual learners, organizes material, is relatively easy to customize to specific audiences, provide text and graphics together and can use special effects to emphasize key learning points. However, he claims that it can make a good teacher bad or a bad teacher worse if power point becomes a crutch, or notes placed on slides that are read from.

Barriers: A teacher cannot interact with database to illustrate points raised by students. Students learn better when they can watch the word being written and the diagram being drawn, such as on a flip chart/chalk board which helps them to better absorb the information and also give them time to ask questions. Power Point hand outs are expensive and time consuming for students to acquire. In preparing the PowerPoint, the student must ensure the environment is suitable for installation of equipment, ensure the room is big enough to accommodate the learners and all can see the screen and lightening and darkening arrangements including note taking are perfect. In a study to assess the perceived effectiveness of the instructional technology package implemented at a regional Midwestern University, an online survey was administered, with 971students and 44 teachers responding. The results indicated attitudes of both students and teachers were positive. Both believed that web and specifically blackboards course info, are beneficial educational tools. They felt confident in their ability to utilize both and considered themselves computer literates. Teachers, significantly more than students, believed both teacher- student and student- student communication were facilitated (Jones, 2005).It is clear that students benefit from activities that focus their study time and help them draw connections between textual information and lecture content. Power point handouts are well suited for study guides of this sort. Instructors are reluctant to distribute handouts of power point presentation prior to class for fear that students will see them as substitutes for lecture and fail to attend the actual session. Others balk at the idea of distributing handouts as students enter the lecture hall, worrying that students won't pay attention during class or fail to develop good notes taking skills. Students may have the impression that everything that one needs to know is included in the handout. When used appropriately, handouts can improve student learning by structuring study time, encouraging critical thinking, preparing students for lecture, and providing opportunities for active learning during the course of the session.

\subsubsection{Handouts}

In the classroom today teachers use many different tools to educate their students. One of the most used tools and one that is usually relied on by most teachers of all grades is the handout. This is a worksheet that is prepared by teachers to help educate the student in the subject that is being taught in class. It helps to classify the material that is presented to students through lectures, books and others. Despite the use of computers in classrooms today, print handouts are still an integral and 
important part of the classroom, "prepare handouts that pertain to that particular lesson" (Gayle, 2001). Doyle and Robson (2002) hold that it is good practice to test the instructions with colleagues to ensure information is clear and correct. They further recommend that handouts should be "directly related to the lesson content". Handouts distributed at the start of a session are usually placed at the entrances of the lecture theatres for collection as students walk in.

\subsubsection{Flipcharts}

According to Elisabeth (2011) the flip chart is by far, the most used teaching tool available to teachers, for many reasons. Primarily because it helps you teach all learning styles and give you options that slide show presentations can't provide: For visual learners, they provide colour, word and images that become memorable pictures in their minds and, hence, easy to remember. And since you are standing in front of the flipcharts to write, they can't wait to read what you have written. For auditory learners, because the teachers will have everyone read what they wrote on the flip chart, the students get a chance to not only hear information but say the information themselves, which helps make the information stick. For kinesthetic learners, they experience the movement in the actual creation of the words and images and this helps them remember the information at a deeper level. The information becomes visceral in a way. The following are the tips for effective use of flipcharts. Plan your chart, know what you want to put on each page and do not make a mistake of putting too much on each sheet, practice drawing the pages for good presentation, when writing stand in front of the chart to provoke curiosity in learners The above researcher identified the following barriers /attitudes to the use of flipcharts by teachers: They do not have time to use flipcharts or develop flipchart skills; they cannot draw and have no time to learn; assuming one's material is far too technical and complicated, and just would not "work" on a flipchart; and learning flipcharts skills has been tried before with perceived bad results. Perhaps a chart comes out looking confusing, you are concerned no one can read your writing, or you don't think you can draw.

\subsubsection{Manikins}

Today's high tech manikins accurately simulate the human body and give students the opportunity to practice procedures. Students can insert IV lines, perform intubations, tracheotomies and Heimlich manoeuvre, treat wounds, detect arrhythmic heartbeats, and listen to bowel sounds. The advent of manikins in the nineties replaced the "sticking an orange" story. Student nurses practiced injections on oranges, which was not realistic. When it came time to stick a needle into the real patient student nurses were nervous to do so. The orange is a bad substitute for patient and the patient is too real for first-timer mistakes. Between these two extremes lies the high tech manikins (Jose' Alaniz, 2000).Manikins are not sensitive to touch and cannot complain if roughly handled. Hence, students are instructed to position them correctly, keep a straight alignment and beware of patient sensitivity. As a nurse being gentle does make a difference in the real world. Student nurses must learn that on manikins. Nurse teachers welcomed this new technology and were very happy to use it in teaching as this was as near as possible to the real patient. They no longer guide the students' hands when it comes to injecting the real patient. Nurse teachers need that hands-on training and time to be knowledgeable enough to manipulate the manikins (ibid).However, good things are never cheap to get. The high cost of the high tech manikins makes it difficult for most nursing schools to acquire and therefore not usually available especially in the developing counties of sub-Saharan origin. Lack of knowledge in operating the manikins is another barrier to their use. Fear of being unable to perform in front of the students is a big problem to unprepared teachers. A number of researchers agree that models are used to teach topics for which specimens are hard to find or real specimens are illegal or dangerous to demonstrate on. They are authentic, three dimensional, sometimes inexpensive and readily available and experience may be tactile/auditory as well as visual (Tambo, 2003).

\section{Area Of Study}

The South-West Region of Cameroon constitutes part of the territory of the then Southern Cameroon with Buea as its capital. Along with the North-West Region, it is one of the two Anglophone (English-speaking) regions of Cameroon. The region is divided into six divisions: Fako, Koupe- 
Muanengouba, Lebialem, Manyu, Meme, and Ndian which are in turn broken down into subdivisions. Important towns include; Buea, Limbe, Tiko, Kumba, and Mamfe. The population is heterogeneous with inhabitants from all over Cameroon and some neighbouring countries like Nigeria and Equatorial Guinea. This region enjoys a tropical climate and agriculture and fishing are the key livelihood occupations for the greater part of the rural population. The region is gifted with very beautiful scenery with plantations and mount Cameroon. Agriculture is one of the major activities in this region. The two main types of agricultural practices include; plantation agriculture and subsistence farming. Limbe in particular is a popular tourist resort notable for its fine beaches and the Korup National Park is also a major attraction. The region is notable for having the first English-speaking University in Cameroon, the University of Buea. The following authorized nursing schools are found in this region: Faculty of Heath Sciences, University of Buea, and Higher Institute of Applied Medical Sciences, Buea, St. Francis Higher Institute of Nursing and Midwifery, Buea, Maflekumen Higher Institute of Health Sciences, Tiko, State Registered Nursing School Limbe and Training School for Nurse Assistant, Limbe.

The North-West Region is found in the western highlands of Cameroon. It is bordered to the south by the West Region, to the east by Adamawa Region, and to the north by the Federal Republic of Nigeria. It is the third most populated Region in Cameroon. It has one major metropolitan city; Bamenda with several other smaller towns such as Batibo, Mbengwi, Wum, Kumbo, Nkambe. Like other Regions in Cameroon, the North-West Region is made up of administrative divisions; seven in number: Mezam, Momo,Ngo-Ketunjia, Boyo, Menchum, Bui and Donga-Mantung. The economy of the region is highly rooted in agriculture. Food crops include rice, Irish potatoes, maize, beans, sweet potatoes, plantains, coco yams, cassava and yellow yams are the food staples for the region.

The following authorized nursing schools are found in this region: University of Science and Technology, St. Louis Higher Institute of Health and Biomedical Sciences, National PolytechniqueBambui, Capitol Higher Institute of Health Sciences, State Registered Nursing School Bamenda, Training School for Nurse Assistant Bamenda and Training School for Certified Midwives Bamenda.

\section{Methodology}

The Research Methodology refers to the process and the steps in the research process.

\subsection{Research Design}

According to Pilot (1987), research design is the plan and structure of investigation. The research design selected for this study was the descriptive survey design. It was because the study sampled the opinions of the respondents in relation to the phenomena under investigation. Accordingly, a questionnaire was used to gather the data. Two main approaches were used in the research: quantitative and qualitative. Quantitative research deals principally with numerical data while qualitative research deals with verbal data. Thus the nature of data collected in this research led the researcher to decide on combined quantitative / qualitative approaches.

\subsection{Study Population}

A target population according to Nworgu (1991) is that population to which the findings of a study are generalized. In this study, the target population was made up of all the nurse teachers, from authorized public and private nursing schools in the South West and North West Regions of Cameroon.

Table1. Names of Nursing Schools and nurse teacher population in the South West Region

\begin{tabular}{|l|l|}
\hline Names of Nursing Schools & Population \\
\hline Higher Institute of Applied Medical Sciences, Buea & 7 \\
\hline St. Francis Institute of Nursing \& Midwifery Bokoko-Buea & 14 \\
\hline Faculty of Health Sciences, University of Buea & 5 \\
\hline Maflekumen Higher Institute of Health Sciences, Tiko & 4 \\
\hline State Registered Nursing School Limbe & 10 \\
\hline
\end{tabular}


The Importance of Instructional Materials in Nurse Education in the North West and South West Regions of Cameroon: The Nurse Teacher's Perspective

\begin{tabular}{|l|l|}
\hline Training School for Nurse Assistant Mamfe & 5 \\
\hline Training School for Nurse Assistant Limbe & 6 \\
\hline Directors/Heads of Departments (nurse teachers) & 4 \\
\hline Sub Total & $\mathbf{5 5}$ \\
\hline
\end{tabular}

Table2. Names of Nursing Schools and Nurse Teacher Population in the North West Region

\begin{tabular}{|l|l|}
\hline Names of Nursing Schools & Population \\
\hline St. Louis Higher Institute of Health \& Biomedical Sciences Bamenda & 6 \\
\hline National PolytechniqueBambui & 6 \\
\hline Bamenda University of Science \& Technology & 8 \\
\hline Capitol Higher Institute of Health Sciences & 5 \\
\hline State Registered Nursing School Bamenda & 8 \\
\hline Training School for Nurse Assistant Bamenda & 6 \\
\hline Training School for Certified Midwives & 6 \\
\hline Directors (nurse teachers) & 5 \\
\hline Sub total & 50 \\
\hline Grand total & $\mathbf{1 0 5}$ \\
\hline
\end{tabular}

\subsection{Sample and Sampling Technique}

The sample for this study was 91 made up of all the nurse teachers of eleven selected nursing schools from the fourteen authorized public and private nursing schools in South West and North West Regions of Cameroon. The sampling technique used was the purposive sampling technique. The researcher purposefully selected eleven nursing schools from North West and South West Regions; 6 from North West Region and 5 from South West Region (6 governments and 5 private). These constituted a sample size of 91 for the study. Questionnaires were distributed to them and 76 responded giving 84\% response rate. In the South West Region, two authorized nursing schools Maflekumen and Training School for Nurse Assistant Mamfe were not included because Maflekumen was used for the pilot study and Mamfe was inaccessible. Capitol Higher Institute of Health Sciences Bamenda was also left out because the nurse teachers were unavoidably absent at the time of questionnaire distribution.

Table3. Summary of Sample size selected for the study

\begin{tabular}{|c|c|c|c|}
\hline $\mathbf{S} / \mathbf{N}$ & Region & Surveyed institutions & $\begin{array}{l}\text { Number of nurse } \\
\text { teachers including } \\
\text { HODs and Directors }\end{array}$ \\
\hline 1 & \multirow{6}{*}{ South West } & Faculty of Health Sciences, University of Buea & 5 \\
\hline 2 & & Higher Institute of Applied Medical Sciences Buea & 7 \\
\hline 3 & & $\begin{array}{l}\text { St. Francis Higher Institute of Nursing \& Midwifery } \\
\text { BokokoBuea }\end{array}$ & 14 \\
\hline 4 & & State Registered Nursing School Limbe & 10 \\
\hline \multirow[t]{3}{*}{5} & & Training School for Nurse Assistant Limbe & 6 \\
\hline & & HODs/Directors (nurse teachers) & 4 \\
\hline & Sub total & & 46 \\
\hline 6 & \multirow{7}{*}{ North West } & $\begin{array}{l}\text { St. Louis Higher Institute of Health \& Biomedical } \\
\text { Sciences Bamenda }\end{array}$ & 6 \\
\hline 7 & & Bamenda University of Science \& Technology & 8 \\
\hline 8 & & National PolytechniqueBambui & 6 \\
\hline 9 & & State Registered Nursing School Bamenda & 8 \\
\hline 10 & & Training School for Nurse Assistant Bamenda & 6 \\
\hline 11 & & Training School for Certified Midwives & 6 \\
\hline 12 & & Directors (nurse teachers) & 5 \\
\hline & Sub total & & 45 \\
\hline & Grand total & & 91 \\
\hline
\end{tabular}

\section{INSTRUMENTATION}

One instrument was used to gather data for analysis. The instrument was a questionnaire, which was designed for nurse teachers, including their HODs and Directors. It was designed in sections to address the three objectives of the study; Actual use, Barriers and Attitudes. Questions were 
constructed using a matrix format to use space efficiently and hopefully encourage a faster completion time than a questionnaire with largely open-ended questions. The questionnaire contained clear instructions on how to complete it. Open-ended and close-ended questions were included in this questionnaire. Closed-ended questions were used because they are quicker and easier for the respondents to answer and for the data to be analyzed. The main advantage here was that close-ended questions forced respondents to give simplistic responses to complex issues. Openended questions were used because they allowed respondents to be creative and express themselves when responding to the questions. Care was taken not to include too many open-ended questions because it could be time consuming to answer and analyze and could be liable to errors (Neumann, 2000). Certain questions had follow-up questions. They were specifically included to obtain more information about a previously asked question. The questionnaire helped to obtain in-depth knowledge about the research problem. The questions in the questionnaire were arranged in content subsection. The questions in each subsection were relevant to its content. At the introduction of the questionnaire, brief information about the research was given together with instructions on how to complete the questionnaire. The nurse teachers were expected to answer all questions as the questions were clearly worded to avoid ambiguity. The questions were also clearly spread out and uncluttered. The questionnaire consisted of seven pages. Questions pertaining to Demographic data were considered non-threatening and thus were placed at the beginning of the questionnaire. These were followed by questions on Actual use of instructional materials, Barriers to the use of instructional materials, and Attitudes towards the use of instructional materials.

The following measurements were put in place to measure the responses in respect of the variables under investigation.

In section B: Actual use of instructional materials, the responses for item 1: How would you grade yourself in the use of the following instructional materials? Were graded on a scale of A-F thus: $A=$ 80-100, B+= 70-79, B= 60-69, C+=55-59, D=40-44, C=50-54, F=0-39, D+=45-49

Item 2: "Statements in respect to your actual use of each instructional material". Response options "Agree or Disagree" graded 4-1 from Strongly Agree to Strongly Disagree was used thus:

Strongly agree $(\mathrm{SA})=4$ Disagree $(\mathrm{D})=2$ Agree $(\mathrm{A})=3 \quad$ strongly Disagree $=1$

In Section D: Attitudes towards the use of instructional materials.

Item 1 "To what extent will you recommend the use of each of the following instructional materials to a beginning nurse teacher?" Measuring scale: Strongly Recommend; Recommend; Not Recommend, Strongly not recommend.

Item 2: To capture attitudes towards the use of 5 instructional materials. Measuring scale: Very Positive Attitude $(\mathrm{VPA})=4$, Positive Attitude $(\mathrm{PA})=3$, Negative Attitude (NA) $=2$ Very Negative Attitude $(\mathrm{VNA})=1$

Item 3: "To what extent would you respond that instructional materials are "tools for teaching and avenues for learning"? Measuring scale used: Strongly agree (SA) =4, Agree (A) =3 Disagree (DA) $=2$ Strongly Disagree $(\mathrm{SDA})=1$

\subsection{Validity of the Instrument}

Validity refers to a degree to which an instrument measures what it is supposed to be measuring. The questionnaire was validated in two phases face and content:

Face validity was achieved when the researcher handed a copy of the questionnaire to her supervisor after construction for corrections. The supervisor went through it diligently, deleting some items and correcting some. Alongside the researcher, the supervisor advised on the inclusion of some items, and the structure for each section. After this the questionnaire was subjected to content validity.

Content validity was achieved through a pilot study conducted on 4 teachers of Maflekumen Higher Institute of Health Sciences, Tiko who formed part of the population but were not involved in the sample. The researcher administered the questionnaire on them. Their responses were collected and evaluated in line with the objectives of the study. It was discovered that, these responses could be 
The Importance of Instructional Materials in Nurse Education in the North West and South West Regions of Cameroon: The Nurse Teacher's Perspective

used to ascertain the attainment of the specific objectives of this study.

\subsection{Reliability of the Instrument}

The reliability of an instrument is the degree of consistency with which it measures the attribute it is supposed to be measuring for example, a scale that measures the same item with different scores is not reliable. The test - retest method was used to determine the reliability of the instrument. To do this, the same respondents ( 4 in number) who were used to ascertain content validity were readministered the same but a fresh set of the questionnaire two weeks later. A comparison was made in the results of the two tests. The level of similarity of the two sets of responses was very highly estimated at about $97 \%$. This led the researcher to conclude that the instrument was reliable and fit for administration. The difference in the two results was noticed on the responses of one respondent who indicated their school was located in urban area when answering the test at the pilot phase but indicated rural two weeks later.

\section{Methods of Data Analysis}

All data collected were coded using 1 and 2 for dichotomous variables and numbers ranging from 1 to 8 for multiple variables. All coded data were entered in version Statistical Package for Social Sciences file 17 (2010) Atlanta Georgia. Specifically, frequencies, percentages, means, standard deviations and bar-charts were the descriptive statistics used.

\subsection{Presentation of Findings}

\subsubsection{Actual Use of Instructional Materials}

Table4. Frequency and Percentage Breakdown of Respondents in Relation to Gender and the Actual Use of the Chalkboard

\begin{tabular}{|c|c|c|c|c|c|c|c|c|c|c|c|c|c|c|}
\hline \multirow{3}{*}{ Gender } & \multirow{3}{*}{$\begin{array}{l}\text { Freque } \\
\text { ncy (f) }\end{array}$} & \multirow{3}{*}{$\begin{array}{l}\text { Percenta } \\
\text { ge }(\%)\end{array}$} & \multicolumn{12}{|c|}{ Actual Use Expressed in Grades } \\
\hline & & & \multicolumn{2}{|c|}{ A } & \multicolumn{2}{|c|}{$\mathbf{B}^{+}$} & \multicolumn{2}{|l|}{ B } & \multicolumn{2}{|c|}{ C } & \multicolumn{2}{|c|}{$\mathbf{D}^{+}$} & \multicolumn{2}{|c|}{$\begin{array}{l}\text { Missing } \\
\text { data }\end{array}$} \\
\hline & & & $\mathbf{f}$ & $\%$ & $\mathbf{f}$ & $\%$ & $\mathbf{f}$ & $\%$ & f & $\%$ & $\mathbf{f}$ & $\%$ & $\mathbf{F}$ & $\%$ \\
\hline Male & 39 & 51.3 & 27 & 48.2 & 8 & 61.5 & 3 & 75.0 & 1 & 50.0 & 1 & 100.0 & 1 & 50.0 \\
\hline Female & 37 & 48.7 & 29 & 51.8 & 5 & 38.5 & 1 & 25.0 & 1 & 50.0 & - & - & 1 & 50.0 \\
\hline Total & 76 & 100.0 & 56 & 100 & 13 & 100 & 4 & 100 & 2 & 100 & 1 & 100 & 2 & 100 \\
\hline
\end{tabular}

Table 4 showed that, out of 76 respondents, 56 scored A grades in the Actual Use of the Chalkboard. More females (51.8\%) scored A grades than males (48.2\%). Out of 13 who scored $\mathrm{B}^{+}, 61.5 \%$ were males while $38.5 \%$ were females. For $\mathrm{C}$ grades, there was no gender disparity as each scored $50 \%$. For $\mathrm{D}^{+}$grades, only 1 respondent (male) scored this grade. An overall rating reflected actual use of the Chalkboard.

Table5. Frequency and Percentage Breakdown of Respondents in Relation to Highest Professional Qualification and the Actual Use of the Chalkboard

\begin{tabular}{|c|c|c|c|c|c|c|c|c|c|c|c|c|}
\hline \multirow{3}{*}{$\begin{array}{l}\text { Highest } \\
\text { Professional } \\
\text { Qualification }\end{array}$} & \multirow{3}{*}{$\begin{array}{l}\text { Freque } \\
\text { ncy (f) }\end{array}$} & \multirow{3}{*}{$\begin{array}{l}\text { Percenta } \\
\text { ge }(\%)\end{array}$} & \multicolumn{10}{|c|}{ Actual Use Expressed in Grades } \\
\hline & & & \multicolumn{2}{|l|}{$\mathbf{A}$} & \multicolumn{2}{|l|}{$\mathbf{B}^{+}$} & \multicolumn{2}{|l|}{ B } & \multicolumn{2}{|c|}{$\mathbf{C}$} & \multicolumn{2}{|c|}{$\mathrm{D}^{+}$} \\
\hline & & & $\mathbf{f}$ & $\%$ & $\mathbf{f}$ & $\%$ & $\mathbf{f}$ & $\%$ & $\mathbf{f}$ & $\%$ & $\mathbf{f}$ & $\%$ \\
\hline $\begin{array}{l}\text { Bachelor of } \\
\text { Nursing }\end{array}$ & 17 & 22.4 & 11 & 19.6 & 4 & 33.4 & 1 & 16.7 & 1 & 100 & - & - \\
\hline Masters Degree & 13 & 17.1 & 9 & 16.1 & 2 & 16.7 & 2 & 33.2 & - & - & - & - \\
\hline $\begin{array}{ll}\text { Advanced } & \text { Diploma } \\
\text { in Nursing } & \\
\end{array}$ & 11 & 14.5 & 8 & 14.3 & 2 & 16.7 & 1 & 16.7 & - & - & - & - \\
\hline TSSI & 8 & 10.5 & 6 & 10.7 & 1 & 8.3 & 1 & 16.7 & - & - & \begin{tabular}{|l|}
- \\
\end{tabular} & - \\
\hline $\begin{array}{l}\text { Diploma in Nursing } \\
\text { Administration }\end{array}$ & 6 & 7.9 & 4 & 7.1 & 1 & 8.3 & 1 & 16.7 & - & - & - & - \\
\hline $\begin{array}{l}\text { State Certified } \\
\text { Midwifery }\end{array}$ & 4 & 5.2 & 4 & 7.1 & - & - & - & - & - & - & - & - \\
\hline $\begin{array}{l}\text { Diploma in } \\
\text { Ophthalmology }\end{array}$ & 4 & 5.2 & 4 & 7.1 & - & - & - & - & - & - & - & - \\
\hline ITMS & 4 & 5.2 & 3 & 5.4 & 1 & 8.3 & - & - & - & - & - & - \\
\hline Missing Data & 4 & 5.2 & 4 & 7.1 & - & - & - & - & - & - & \begin{tabular}{|l|l}
- \\
\end{tabular} & - \\
\hline
\end{tabular}

International Journal of Humanities Social Sciences and Education (IJHSSE) 
The Importance of Instructional Materials in Nurse Education in the North West and South West Regions of Cameroon: The Nurse Teacher's Perspective

\begin{tabular}{|l|l|l|l|l|l|l|l|l|l|l|l|l|}
\hline $\begin{array}{l}\text { Diploma in Lab } \\
\text { Technology }\end{array}$ & 2 & 2.6 & 2 & 3.7 & - & - & - & - & - & - & - & - \\
\hline Ph.D. & 2 & 2.6 & - & - & 1 & 8.3 & - & - & - & - & 1 & 100 \\
\hline B.Sc. Biochem & 1 & 1.6 & 1 & 1.8 & - & - & - & - & - & - & - & - \\
\hline Total & $\mathbf{7 6}$ & $\mathbf{1 0 0}$ & $\mathbf{5 6}$ & $\mathbf{1 0 0}$ & $\mathbf{1 2}$ & $\mathbf{1 0 0}$ & $\mathbf{6}$ & $\mathbf{1 0 0}$ & $\mathbf{1}$ & $\mathbf{1 0 0}$ & $\mathbf{1}$ & $\mathbf{1 0 0}$ \\
\hline
\end{tabular}

Results on Table 5 show that, $1 \mathrm{PhD}$ fellow scored $\mathrm{B}+, 9$ masters degree holders scored A grades, 2 Masters degree holders scored $\mathrm{B}+$, another 2 masters degree holders scored $\mathrm{B}$. These constituted 67\%. Lower qualified staff, (33\%) Diploma in Nursing Administration scored 4 A grades, 4 State Certified Midwives scored $4 \mathrm{~A}$ grades. This means that on the overall highly qualified teachers used the chalkboard more $(67 \%)$ than lower qualify staff constituting $33 \%$. In general, the chalkboard is mostly; as 56 out of 76(74\%) respondents scored A grades, 12 scored $\mathrm{B}^{+}, 6$ scored B, 1 scored C, and 1 scored $\mathrm{D}^{+}$.

Table6. Frequency and Percentage Breakdown of Respondents, Relating to Longevity in the Teaching Profession and Actual Use of the Chalkboard

\begin{tabular}{|c|c|c|c|c|c|c|c|c|c|c|c|c|c|c|}
\hline \multirow{3}{*}{$\begin{array}{l}\text { Longevity in } \\
\text { the teaching } \\
\text { profession }\end{array}$} & \multirow{3}{*}{ (f) } & \multirow{3}{*}{$(\%)$} & \multicolumn{12}{|c|}{ Actual use of the chalkboard in Grades } \\
\hline & & & \multicolumn{2}{|l|}{$\mathrm{A}$} & \multicolumn{2}{|l|}{$\mathrm{B}^{+}$} & \multicolumn{2}{|c|}{$\mathrm{B}$} & \multicolumn{2}{|l|}{$\mathrm{C}$} & \multicolumn{2}{|c|}{ Missing } & \multicolumn{2}{|c|}{$\mathrm{D}^{+}$} \\
\hline & & & $\mathrm{f}$ & $\%$ & $\mathrm{f}$ & $\%$ & $\mathrm{f}$ & $\%$ & $\mathrm{f}$ & $\%$ & $f$ & $\%$ & $\mathrm{f}$ & $\%$ \\
\hline $1-5$ years & 33 & 43.4 & 23 & 41.1 & 4 & 30.8 & 3 & 75.0 & 2 & 100 & - & - & 1 & 100 \\
\hline $\begin{array}{l}\text { Above } 20 \\
\text { years }\end{array}$ & 16 & 21.1 & 13 & 23.2 & 3 & 23.1 & - & - & - & - & - & - & - & - \\
\hline $6-10$ years & 13 & 17.1 & 8 & 14.3 & 4 & 30.8 & 1 & 25.0 & - & - & - & - & - & - \\
\hline $11-15$ years & 9 & 11.8 & 7 & 12.5 & 2 & 15.3 & - & - & - & - & - & - & - & - \\
\hline $16-20$ years & 5 & 6.6 & 5 & 8.9 & - & - & - & - & - & - & - & - & - & - \\
\hline Total & 76 & 100 & 56 & 100 & 13 & 100 & 4 & 100 & 2 & 100 & - & - & 1 & 100 \\
\hline
\end{tabular}

Results on Table 6 show that relatively, 57.9\% respondents who have taught for many years scored A grades. Out of 16 respondents who taught for above 20 years, 13 had A grades (81\%). All who taught for 16 to 20 years scored A grades. 7 out of 9 who taught for 11 to 15 years scored A grades. 8 out of 13 who taught for 6 to 10 years scored A grades, while 23 out of 33(70\%) who taught for 1 to 5 years also scored A grades. The results indicated that respondents who have taught for 6-20 years used the chalkboard more than those who have taught for 1-5years.

\subsubsection{Weighted Means and Standard Deviations to Assess Actual Use}

In this section the responses were weighted on a scale of 4 for each item on the questionnaire. Any respondent who ticked Strongly Agree (SA) scored 4 points, Agree (A) scored 3 points, Disagree (DA) scored 2 points and Strongly Disagree (SDA) scored 1 point. The means and standard deviations for each item were computed.

Table7. Descriptive Analyses on the Actual Use of the Chalkboard

\begin{tabular}{|c|c|c|c|c|c|c|c|}
\hline \multirow{2}{*}{$\mathbf{S} / \mathbf{N}$} & \multirow{2}{*}{$\begin{array}{l}\text { Statement on the Actual Use of the } \\
\text { Chalkboard }\end{array}$} & SA & $\mathbf{A}$ & DA & SDA & \multirow{2}{*}{$(\bar{X})$} & \multirow{2}{*}{$\begin{array}{l}\text { Standard } \\
\text { Deviation } \\
\text { (SD) }\end{array}$} \\
\hline & & $\mathbf{f}$ & $\mathbf{f}$ & f & $\mathbf{f}$ & & \\
\hline 1. & $\begin{array}{l}\text { I ensure that what is written on the } \\
\text { chalkboard is not hidden from students. }\end{array}$ & 56 & 20 & - & - & 3.737 & 1.010 \\
\hline 2. & I usually keep the chalkboard clean after use. & 33 & 29 & 14 & - & 3.25 & 0.987 \\
\hline 3. & $\begin{array}{l}\text { I write or draw large enough for everyone in } \\
\text { the class to see. }\end{array}$ & 16 & 53 & 7 & - & 3.118 & 1.110 \\
\hline 4. & $\begin{array}{l}\text { I ensure that chalk, cleaning cloths, rulers } \\
\text { and related items are readily available to } \\
\text { avoid interruption of the lesson. }\end{array}$ & 38 & 22 & 06 & 10 & 3.158 & 0.910 \\
\hline \multicolumn{6}{|c|}{ Overall Mean } & 3.316 & \\
\hline
\end{tabular}

An overall mean of 3.316 means that the chalkboard is actually being used since $3.0 \leq 3.316 \leq 4.0$.

\section{Section C: Barriers to the use of instructional materials}

Specific Objective 2: To identify barriers to the use of the chalkboard, handouts, flipcharts, 
The Importance of Instructional Materials in Nurse Education in the North West and South West Regions of Cameroon: The Nurse Teacher's Perspective

manikins and the Power Points in nurse education.

As shown on Table 8, the major barriers to the use of the chalkboard were: poor surface of the chalkboard scored 74\%; chalk particles may be a health hazard, 57\%; the position and size of the board will not be convenient for learners and the teachers $53 \%$; tedious to use $50 \%$; a short time to display information 5.3\%.

Table8. Frequency and Percentage Breakdown of Respondents in Relation to Barriers to the Use of the Chalkboard

\begin{tabular}{|c|c|c|c|c|}
\hline \multirow{2}{*}{$\mathbf{S} / \mathbf{N}$} & \multicolumn{2}{|l|}{ Barriers } & \multirow{2}{*}{ Freq } & \multirow{2}{*}{$\%$} \\
\hline & Major themes & Sub-themes & & \\
\hline 1. & $\begin{array}{l}\text { Poor surface of the } \\
\text { chalkboard }\end{array}$ & $\begin{array}{l}\text { - } \quad \text { The rough surfaces may render its use difficult. } \\
\text { - } \quad \text { The slippery nature of some surfaces may render its } \\
\text { usage difficult }\end{array}$ & 56 & 73.7 \\
\hline 2. & $\begin{array}{l}\text { Chalk particles may be a } \\
\text { health hazard }\end{array}$ & $\begin{array}{ll}- & \text { When inhaled, causes respiratory problems. } \\
\text { - } & \text { Chalk produces dust which dirties the teacher. } \\
\text { - } & \text { Chalk particles dirty the environment }\end{array}$ & 43 & 56.6 \\
\hline 3. & $\begin{array}{l}\text { The position and size of } \\
\text { the board will not be } \\
\text { convenient for some } \\
\text { learners and the teacher }\end{array}$ & $\begin{array}{l}\text { - Distant positioning of the board may be a problem to } \\
\text { some students. } \\
\text { - If the board is small, it will not contain much } \\
\text { information. } \\
\text { - The height of the board may not be convenient for } \\
\text { the teacher. }\end{array}$ & 40 & 52.6 \\
\hline 4. & Tedious to use & $\begin{array}{l}\text { - If not properly maintained, usage may be difficult. } \\
\text { - There may be the non-availability of different } \\
\text { colours of chalk to match the different colours of the } \\
\text { board. } \\
\text { - The absence of a duster makes its use difficult. }\end{array}$ & 38 & 50.0 \\
\hline 5. & $\begin{array}{l}\text { A short time to display } \\
\text { information. }\end{array}$ & $\begin{array}{l}\text { - Information on it cannot last for long as the next } \\
\text { teacher must make use of the board. }\end{array}$ & 4 & 5.3 \\
\hline
\end{tabular}

Table9. Frequency and Percentage Breakdown of Respondents in Relation to Potential Barriers to the Use of the Chalkboard

\begin{tabular}{|l|l|l|l|}
\hline S/N & Potential Barriers & Frequency (f) & $\begin{array}{l}\text { Percentage } \\
(\%)\end{array}$ \\
\hline 1. & Rough surfaces & 63 & 82.9 \\
\hline 2. & Inability to write well on the board & 45 & 59.2 \\
\hline 3. & Lack of water to wash hands after use & 43 & 56.6 \\
\hline 4. & The non availability of accessories i.e. chalk and duster & 35 & 46.1 \\
\hline 5. & Time constraints & 6 & 7.9 \\
\hline 6. & Missing data & 4 & 5.3 \\
\hline
\end{tabular}

Results on Table 9 have some resemblance with those on table 4.34. Amongst the potential barriers, rough surfaces attracted the interest of most respondents (82.9\%), followed by inability to write well on the board (59.2\%), the non availability of accessories (46.1\%), and time constraints (7.9\%). This means time constrains was the least of their worries.

Table10. Frequency and Percentage Breakdown of Respondents in Relation to the Extent to which they will recommend the Use of the following Instructional Materials

\begin{tabular}{|c|c|c|c|c|c|c|c|c|c|c|c|c|c|}
\hline \multirow{3}{*}{ No. } & \multirow{3}{*}{$\begin{array}{l}\text { Instructional } \\
\text { Materials }\end{array}$} & \multicolumn{12}{|c|}{ Response Options } \\
\hline & & \multicolumn{2}{|c|}{$\begin{array}{l}\text { Strongly } \\
\text { Recomme } \\
\text { nd (SR) }\end{array}$} & \multicolumn{2}{|c|}{$\begin{array}{l}\text { Recomme } \\
\text { nd (R) }\end{array}$} & \multicolumn{2}{|c|}{$\begin{array}{l}\text { Not } \\
\text { Recomme } \\
\text { nd (NR) }\end{array}$} & \multicolumn{2}{|c|}{$\begin{array}{l}\text { Strongly not } \\
\text { Recommend } \\
\text { (SNR) }\end{array}$} & \multicolumn{2}{|c|}{$\begin{array}{l}\text { Missing } \\
\text { Data }\end{array}$} & \multicolumn{2}{|c|}{ Total } \\
\hline & & f & $\%$ & $\mathbf{f}$ & $\%$ & f & $\%$ & f & $\%$ & f & $\%$ & $\mathbf{f}$ & $\%$ \\
\hline 1. & Chalkboards & 56 & 73.7 & 17 & $\begin{array}{l}22 . \\
4\end{array}$ & 2 & 2.6 & 1 & 1.3 & - & - & 76 & 100.0 \\
\hline 2. & Hand Outs & 18 & 23.7 & 38 & $\begin{array}{l}50 . \\
0\end{array}$ & 10 & 13.2 & 6 & 7.8 & 4 & 5.3 & 76 & 100.0 \\
\hline
\end{tabular}


The Importance of Instructional Materials in Nurse Education in the North West and South West Regions of Cameroon: The Nurse Teacher's Perspective

\begin{tabular}{|l|l|l|l|l|l|l|l|l|l|l|l|l|l|}
\hline 3. & Flip Charts & 15 & 19.7 & 54 & $\begin{array}{l}71 . \\
1\end{array}$ & 5 & 6.6 & 1 & 1.3 & 1 & 1.3 & 76 & 100.0 \\
\hline 4. & Manikins & 34 & 44.7 & 25 & $\begin{array}{l}32 . \\
9\end{array}$ & 5 & 6.6 & 4 & 5.3 & 8 & $\begin{array}{l}10 . \\
5\end{array}$ & 76 & 100.0 \\
\hline 5. & Power Point & 24 & 31.5 & 33 & $\begin{array}{l}43 . \\
4\end{array}$ & 10 & 13.2 & 5 & 6.6 & 4 & 5.3 & 76 & 100.0 \\
\hline
\end{tabular}

Table11. Frequency, Mean and Standard Deviation of Responses in Relation to Capturing Attitudes towards the use of Instructional Materials

\begin{tabular}{|l|l|l|l|l|l|l|l|l|}
\hline \multirow{3}{*}{ No. } & \multirow{3}{*}{$\begin{array}{l}\text { Instructional } \\
\text { Material }\end{array}$} & VPA (4) & $\begin{array}{l}\text { PA } \\
(3)\end{array}$ & $\begin{array}{l}\text { NA } \\
(\mathbf{2})\end{array}$ & $\begin{array}{l}\text { VNA } \\
(\mathbf{1})\end{array}$ & $\begin{array}{l}\text { Missing } \\
\text { Data }\end{array}$ & $\begin{array}{l}\text { Mean } \\
(\bar{X})\end{array}$ & $\begin{array}{l}\text { Standard } \\
\text { Deviation } \\
\text { (SD) }\end{array}$ \\
\cline { 3 - 10 } & & $\mathbf{f}$ & $\mathbf{f}$ & $\mathbf{f}$ & $\mathbf{f}$ & F & & \\
\hline 1. & Chalkboards & 41 & 29 & 4 & 2 & - & 3.421 & 0.666 \\
\hline 2. & Handouts & 23 & 47 & 6 & - & - & 3.303 & 0.941 \\
\hline 3. & Flip charts & 11 & 49 & 10 & 2 & 4 & 2.789 & 1.010 \\
\hline 4. & Manikins & 43 & 25 & 4 & - & 4 & 3.355 & 0.871 \\
\hline 5. & Power Point & 35 & 24 & 7 & 3 & 7 & 3.013 & 0.517 \\
\hline
\end{tabular}

A mean of 3 and above meant that most respondents had a very positive attitude towards the use of the following instructional materials: chalkboard, handouts, manikins and power point. A mean of between 2 and 2.99 meant that most respondents had a positive attitude towards the use of flipcharts. All the standard deviation values were small, meaning that most of the scores rotated close to the mean.

Table12. Frequency, Mean and Standard Deviation of Responses in Relation to the Statement, "Instructional Materials are Tools for Teaching and Avenues for Learning" in Respect to Each of the Following

\begin{tabular}{|l|l|l|l|l|l|l|l|l|}
\hline \multirow{2}{*}{ No. } & \multirow{2}{*}{$\begin{array}{l}\text { Instructional } \\
\text { Material }\end{array}$} & $\begin{array}{l}\text { Response Options } \\
\text { Strongly } \\
\text { Agree(4) }\end{array}$ & $\begin{array}{l}\text { Agree } \\
(\mathbf{3})\end{array}$ & $\begin{array}{l}\text { Disagree } \\
(\mathbf{2})\end{array}$ & $\begin{array}{l}\text { Strongly } \\
\text { Disagree(1) }\end{array}$ & $\begin{array}{l}\text { Missing } \\
\text { Data }\end{array}$ & $\begin{array}{l}\text { Mean } \\
(\bar{X})\end{array}$ & $\begin{array}{l}\text { Standard } \\
\text { Deviation(SD) }\end{array}$ \\
\cline { 3 - 10 } & & $\mathbf{f}$ & $\mathbf{f}$ & $\mathbf{f}$ & $\mathbf{f}$ & $\mathbf{f}$ & & \\
\hline 1. & Chalkboards & 52 & 21 & 2 & - & 1 & 3.618 & 0.541 \\
\hline 2. & Handouts & 28 & 42 & 4 & - & 2 & 3.237 & 0.672 \\
\hline 3. & Flip charts & 24 & 48 & 2 & - & 2 & 3.184 & 0.963 \\
\hline 4. & Manikins & 45 & 26 & 1 & - & 4 & 3.421 & 0.666 \\
\hline 5. & Power Point & 41 & 25 & 3 & 1 & 6 & 3.539 & 0.848 \\
\hline
\end{tabular}

A mean of 3.00 and above meant that most respondents were very positive to the statement relating to instructional materials as tools for teaching and avenues for learning. This was so for the chalkboards, handouts, flip charts, manikins and power point.

\section{DisCUSSION OF FINDINGS}

Specific Objective 1: To assess the actual use of the chalkboard, handouts, flip charts, manikins, and the power point in nurse education.

In assessing the actual use of the chalkboard, 56 out of 76 respondents (74\%) scored A grades, 13 $(17 \%)$ were rated $\mathrm{B}^{+}$grades, $4(5 \%)$ were rated with $\mathrm{B}$ grades, 2 with $\mathrm{C}$ grades, and 1 with $\mathrm{D}^{+}$. The weighted responses gave an overall mean of 3.316 on a scale of 4.0. This led the researcher to conclude that the chalkboard was actually being used. In the actual use of instructional materials this study found that most respondents $(74 \%)$ used the 5 selected instructional materials especially chalkboard. To use the chalkboard, the study indicated that the following should be maintained: The teacher must ensure that what is written is not hidden from the students, ensure the accessories are available, always keep the board clean after use. Comparing these results to other studies revealed that: These findings were similar to the findings of Farrant (1980) who maintains that the chalkboard is the most common teaching aid, and one of the most useful. For its correct use, teacher must ensure that, what is written is not hidden from the students. From the results of this study, the chalkboard 
registered the highest number of A grades, 56 As. This could be partly due to the fact that it is very easy to use, easy to produce, and does not require very difficult skills to use. Other writers like Tambo (2003), Ashley (2005) and Adeyanju (2003) also argue in line with the findings that for accurate use, teachers must ensure that what is written is not hidden from the students; writing is large enough for it to be readable from all corners of the room; and accessories are in place to avoid disruption of class.

Specific Objective 2: To identify barriers to the use of chalkboard, handouts, flip charts, manikins and power points in nurse education.

In identifying barriers to the use of the chalkboard, the major ones were: poor surface of the chalkboard (73.7\%); chalk particles may be a health hazard $(56.61 \%)$; the position and size of the board will not be convenient for some learners and teachers $(52.6 \%)$; it is difficult to use if not properly maintained (50.0\%); a short time to display information (5.3\%).

\section{CONCLUSION}

This study investigated, "The Use of Instructional Materials in Nurse Education: Actual Use, Barriers and Attitudes: The Nurse Teachers' Perspective". Three objectives were set for investigation, notably: To assess the actual use of chalkboard, handouts, flip charts, manikins and power points; to identify barriers to the use of chalkboards, handouts, flip charts, manikins and power points; to investigate nurse teachers' attitudes towards the use of chalkboards, handouts, flip charts, manikins and power points.

The results showed that; the above teaching aids were evaluated to be very useful instructional materials. Also, the major barriers to their use were identified. The common barriers were financial constraints in producing them, lack of expertise knowledge for their use and time constraints in producing them. If the recommendations that follow are put in place, the actual use of instructional materials in nurse education will be ameliorated.

\section{RECOMMENDATIONS}

- Government should substantially assist schools in the purchase and maintenance of instructional materials, knowing that they play a crucial role in the teaching and learning process. If this is done, then teaching and learning in nursing schools will be ameliorated.

- Computer education should be a must for all Cameroonians from the primary to the secondary to the tertiary institutions. This is because from the results of this study, many respondents had it as a barrier for the use of instructional materials requiring computer knowledge.

- The administration of each nursing school should ensure the availability of running tap for washing of hands after the use of chalkboard.

- The working conditions of teachers should be improved so that, they can have sufficient money to purchase and own instructional materials.

\section{REFERENCES}

[1] Adeyanju, L. (2003). Teachers' perception of the effects and use of learning aids in teaching: a case study of Winneba basic and secondary schools. Available: http:lluttibase.rmit.edu.au/articles/ nov03/adeyanju1.lt

[2] Albright, M. (1996). Instructional Technology and higher education: Rewards, rights and responsibilities.

[3] Arends, R.I. (1997). Classroom Instruction and Management. (3 ${ }^{\text {rd }}$ Ed.). New York: McGraw-Hills companies.

[4] Arends, R.I. (1998). Learning to teach. $\left(3^{\text {rd }}\right.$ Ed.) New York: McGraw Hill, Inc.

[5] Ashley, B. (2005). The advantages of using chalkboard in Teaching in "The Albrightian", The Students' news paper of Albright College-University of Delaware.

[6] Babcode, D.E. and Miller, M.A. (1994). Client education: theory and practice Mosky-Year Book: St. Louis.

[7] Biehler, F.R. \& Snowman, J. (1986). Psychology Applied to teaching. United States of America: 
The Importance of Instructional Materials in Nurse Education in the North West and South West Regions of Cameroon: The Nurse Teacher's Perspective

Houghton Mifflin Company.

[8] Doring, A.H (2009). Integrating Educational Technology into Teaching $4^{\text {th }}$ ed. Canada: Pearson Education.

[9] Doyle, C. \& Robson, K. (2002). Accessible Curricula: good practice for all. Cardiff: UWIC Press.

[10] Elisabeth,W.(2011). Flip Charts: The Proper use for Great Teaching.

[11] Farrant (1980). Principle and practice of education. Essex: Longman

[12] Fitzpatrick, M.L.\&Heller, B.R.(1980).Teaching the teachers to teach. Nursing Outlook 28:372-373.

[13] Gayle, A. B. (2001). Handouts in the classroom: Is Note Taking a lost skill? Available in Grace Konzier, How contributor; updated January 27, 2011.

[14] Gionvanaskis, T.,Samaras, H.\&Tarabanis,K. (2001). Designing a Pedagogically Sound Web based Interface: The Critical Role of Prior Knowledge. In Proceedings of ED MEDIA Conference, Tampere, Finland. Pp592-597

[15] Haggard, A. (1989). Hand book of Patient education. M.D Aspen: Rockville.

[16] Jones, G. H. \& Jones, B. H. (2005). A comparison of Teacher and Student attitudes concerning use and effectiveness of web-based course management software.

[17] Jose' Alaniz(2000). Nursing For Dummies: Life like Mannequins (Manikins) help students sharpen their patient care skills. Gateville Texas: Career Centre "Education".

[18] Kaplan,P.S. (1990). Educational Psychology for tomorrow's teacher. New York: West Publishing Company.

[19] Kent, G. (1969). Blackboard to computer: A guide to educational aid. London: Cox and Wyman Ltd.

[20] Koontz, F.R. (1992). An assessment of teacher attitudes toward selected instructional media. Abstract retrieved April 4, 2005, from http: // www.eric.ed.gov /

[21] Nacino, B. \& Desmond, B. (1992). Curriculum and instruction. London: Macmillan.

[22] Perry, W.G. (1999). Forms of Ethical and Intellectual Development in the College Years. San Francisco: Jossey-Bass publishers.

[23] Piaget, J. (1985). The equilibration of cognitive structures: the central problem of intellectual development. Chicago: University of Chicago Press.

[24] Prieto, L.R. \&Altmaier, E.M. (1994). The relationship of prior training and previous teaching experience to self efficacy among graduate teaching assistants. Research in Higher education 35:481-497.

[25] Princeton, J.C. (1992).The teacher crisis in nursing education-revisited. Nurse Educator 17 5:34-37.

[26] Princeton,J.C.\&Gaspar,T.M. (1991).First-line nurse administrators in academic: How are they prepared, what do they do, and will they stay in their jobs? Journal of Professional Nursing 7 2:79-87.

[27] Quinn, F. (1991). The Principles and Practice of Nurse Education (2 ${ }^{\text {nd }}$ Ed.). London: Chapman and Hall.

[28] Ramsden, P. (2003). Learning to teach in higher education. London: Routledge.

[29] Riding, R. \& Grimley, M. (1999). Cognitive Style and learning from multimedia materials in 11 year old children. British Journal of Educational Technology, 30 (1), 43-59 as cited in AJET. 15(3) McLaughlin (1999). Learning Styles and design of instructional material.

[30] Rogers, C. \& Freiberg, H.J. (1994). Freedom to learn. (3rd Ed.) New York: Macmillan.

[31] Shaffer, D. (2000). Social and Personality Development ( $4^{\text {th }}$ Ed.) Belmont, CA: Wadsworth/Thompson Learning.

[32] Siemen, G. (2005).Connectivism-Qlearning Theory for the digital age. International Journal of Instruction and Distance Learning, 2(1) retrieved July $28^{\text {th }}, 2005$ from; The world wide web http//www.ltdl./ jan-05/article o.lhtm

[33] Skinner, B. (1972). Utopia through the control of human behaviour in John Martin Rich, ed. (1983). Reading in the Philosophy of Education. Belmont, CA: Wadsworth.

[34] Skinner, B. F. (1976). About Behaviourism. New York; Vintage Books.

[35] Smith, L. \& Renzull, J. (1984). Learning style preference: A practical approach for classroom teachers. Theory into practice, 23/1, 45-50.

[36] Tambo, I.L. (2003). Principles and Methods of Teaching; Applications in Cameroon Schools. Limbe: Anucam

[37] Tchombe, T.M. (1997). Classroom events: Methods, Techniques and Psychological Correlates. Yaoundé: Vital press.

[38] Beggs, T. A. (2002). Influences and Barriers to the adoption of instructional technology. State University 
The Importance of Instructional Materials in Nurse Education in the North West and South West Regions of Cameroon: The Nurse Teacher's Perspective

of West Georgia.

[39] Watson, J. (1924). In Crowl, K.T., Kaminsky, S.\&Podell, M.D. (1997). Educational Psychology: Windows on Teaching. United States of America: A times Mirror Company.

[40] Wilkins, E. (1976). Education in practice. London: Evans brother Ltd.

[41] Williams, V.S. \& Dwyer, F. (1999). Effect of metaphoric (visual / verbal) strategies in facilitating student achievement of different educational objectives. International Journal of Instructional Media, 26(2), 205211

\section{AUTHORS' BIOGRAPHY}

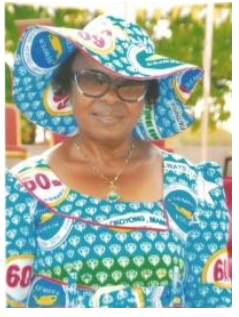

Mrs. Metuge Edna Mesue is a PhD. Research Fellow in the University of Buea and a school administrator (Head of Department of Nursing of the Higher Institute of Applied Medical Sciences, Buea). She holds several certificates in Health Sciences: State Registered Nurse (SRN),Manchester Royal Infirmary, England, United Kingdom; Ophthalmic Nursing Diploma (OND) Manchester Royal Eye Hospital, England, United Kingdom; State Certified Midwife (SCM), North Middlesex Hospital, London England, United Kingdom; Certificate in Nutrition and Child Health, Tropical Child Health Unite, University of London, England, United Kingdom; Advanced Diploma in Teaching Studies for Nursing, University of Ulster, Londonderry, Northern Ireland, United Kingdom; Bachelor of Science with second class honours upper division, University of Ulster, Coleraine, Northern Ireland, United Kingdom; Masters in Nursing Education (MNE Hons), University of Buea, Cameroon. Mrs. Metuge Edna Mesue is a budding researcher with special interest in the psycho-social perspective of teenage pregnancy on secondary school students in Cameroon.

Citation: Metuge Edna Mesue (MNE). "The Importance of Instructional Materials in Nurse Education in the North West and South West Regions of Cameroon: The Nurse Teacher's Perspective ". International Journal of Humanities Social Sciences and Education (IJHSSE), vol 5, no. 3, 2018, pp. 68-84 doi: http://dx.doi.org/10.20431/2349-0381.0503007.

Copyright: (c) 2018 Authors. This is an open-access article distributed under the terms of the Creative Commons Attribution License, which permits unrestricted use, distribution, and reproduction in any medium, provided the original author and source are credited. 